\title{
Technocracy, disaster risk reduction and development: A critique of the Sendai Framework 2015-2030 ${ }^{* * * * * * *}$
}

\section{Tecnocracia, reducción del riesgo de desastres y desarrollo: una crítica al Marco de Sendai 2015-2030}

\section{ABSTRACT}

This article is a criticism of the Sendai Framework for Disaster Risk Reduction 2015-2030 (SFDRR), adopted by the United Nations General Assembly and currently the non-binding international policy on this topic. It deconstructs the SFDRR's technocratic approach to disaster risk reduction, due to natural hazards, given the fact that it invites, paradoxically, to the adoption of policies that increase people's vulnerability. Epistemologically speaking, the SFDRR holds a rationalist understanding of disaster risk, whose origin is in the modernisation theory of development. The undesired outcome of the technocratic understanding of disaster risk is because this approach is not able to trace the grounds of this phenomenon which are the human decisions represented in the social, economic and political structures of society which cause poverty, a vulnerability to disaster risk.

In deconstructing the SFDRR's rationalist understanding of disaster risk, I found this approach is grounded on two paradigms: 1) the idea of discharging on science and technology the responsibility to solve man-made problems such as vulnerability to disaster risk, and 2) the modernization theory of development. These paradigms do not recognize the role of human decisions in creating vulnerability.

LLM International Law with Development, University of Reading, UK. Magíster en Derecho Público, Universidad Externado de Colombia. Abogado de la Pontificia Universidad Javeriana, Cali. Contacto: j.davidosorio@outlook.com. ORCID: 0000-0003-3226-3094.

** Recibido el 14 de febrero de 2020, aprobado el 12 de junio de 2020.

Para citar el artículo: Osorio PIÑERos, J. D. Technocracy, disaster risk reduction and development: A critique of the Sendai Framework 2015-2030. En Revista Derecho del Estado, Universidad Externado de Colombia. N. . 47, septiembre-diciembre de 2020, 319-342.

DOI: https://doi.org/10.18601/01229893.n47.10

*** Este artículo es una adaptación del trabajo de investigación hecho para obtener el título LLM International Law with Development, University of Reading, UK, 2019. 
KEYWORDS

Sendai Framework, Technocracy, Epistemology, Vulnerability, Natural hazards, Poverty, Development.

\section{RESUMEN}

Este artículo es una crítica el Marco de Sendai para la Reducción del Riesgo de Desastres 2015-2030 (MSRRD), que la Asamblea General de las Naciones Unidas adoptó como el actual marco internacional de referencia no vinculante sobre este tema. Esta crítica deconstruye el enfoque tecnocrático que el MSRRD utiliza para comprender qué es el riesgo de desastres por eventos de la naturaleza, porque paradójicamente este enfoque promueve la adopción de políticas que aumentan la vulnerabilidad de las personas a este fenómeno. Hablando en términos epistemológicos, el MSRRD presenta una aproximación racionalista al riesgo de desastres. La señalada paradoja ocurre porque el enfoque tecnocrático no está diseñado para establecer cómo la conducta humana que se refleja en la estructura social, económica y política de la sociedad es un factor causal de vulnerabilidad al riesgo de desastres.

Con la deconstrucción que el artículo desarrolla, se demuestra que el MSRRD se fundamenta en los siguientes paradigmas: 1) la idea de descargar en la ciencia y la tecnología la responsabilidad de resolver los problemas creados por el hombre, como por ejemplo la vulnerabilidad al riesgo de desastre, y 2) la modernización como teoría del desarrollo. Estos paradigmas no reconocen a la conducta humana como factor causal de vulnerabilidad.

PALABRAS CLAVE

Marco de Sendai, tecnocracia, epistemología, vulnerabilidad, eventos de la naturaleza, pobreza, desarrollo.

\section{CONTENTS}

Introduction. 1. The international policy evolution in understanding disaster risk: 1987-2030. 2. Poverty and vulnerability to disaster risk. 3. Epistemological models of risk: rationalist and constructionist. 4. Technocracy and man-made problems. 5. Disaster risk and the modernisation theory of development. Conclusion. References.

\section{INTRODUCTION}

In 2015, the United Nations General Assembly (UNGA) adopted the Sendai Framework for Disaster Risk Reduction 2015-2030 (SFDRR), which is the current 
international non-binding policy on disaster risk reduction. ${ }^{1}$ This framework deals with natural and man-made hazards leading to this phenomenon, and its aim is to achieve "[t]he substantial reduction of disaster risk." this target, the SFDRR incorporates four priorities for action: 1 . understanding disaster risk, 2. strengthening disaster risk governance to manage disaster risk, 3. investing in disaster risk reduction for resilience and 4. enhancing disaster preparedness for effective response and to "Build Back Better" in recovery, rehabilitation and reconstruction. ${ }^{3}$ At the same time, paragraph six of the SFDRR calls to tackle the "underlying disaster risk drivers, such as the consequences of poverty and inequality."

Despite the first SFDRR's priority for action is understanding disaster risk, this framework does not define this concept; it mentions this phenomenon should be understood "in all its dimensions of vulnerability, capacity, exposure of persons and assets, hazard characteristics and the environment." Nonetheless, the 2016 Report of the Open-Ended Intergovernmental Expert Working Group defines it as " $[\mathrm{t}] \mathrm{he}$ potential loss of life, injury, or destroyed or damaged assets, which could occur to a system, society or a community in a specific period of time, determined probabilistically as a function of hazard, exposure, vulnerability and capacity."

For the purpose of this article, I want to highlight the 2016 Report definition of vulnerability, " $[t]$ he conditions determined by physical, social, economic and environmental factors or processes which increase the susceptibility of an individual, a community, assets or systems to the impacts of hazards" as well as the meaning of hazard, "[a] process, phenomenon or human activity that may cause loss of life, injury or other health impacts, property damage, social and economic disruption or environmental degradation." ${ }^{\prime 8}$ Then, disaster risk is the outcome of the interaction between vulnerabilities and hazards. ${ }^{9}$

In this article, I discuss to what extent does the SFDRR's technocratic understanding of disaster risk ignores poverty, but recognises its consequences, as a vulnerability to this phenomenon. In my opinion, this approach restrains

1 United Nations General Assembly. Sendai Framework for Disaster Risk Reduction 2015-2030. Res 69/283. 23 June 2015. (Hereinafter UNGA and SFDRR, respectively).

2 Ibid., para 16, 17.

3 Ibid., para 20.

4 Ibid., para 6; emphasis added.

$5 \quad$ Ibid., para 23.

6 United Nations General Assembly. Report of the Open-Ended Intergovernmental Expert Working Group on Indicators and Terminology Relating to Disaster Risk Reduction. Res 71/644. 14. 1 December 2016.

7 Ibid.

8 Ibid.

9 ARONSSON-STORRIER, M. Sendai five years on: Reflections on the role of International Law in the creation and reduction of disaster risk. In International Journal of Disaster Risk Science. Vol. 11, Issue 2, 2020, 231. 
disaster risk reduction policies to focus on the root of vulnerability such as the social, economic and political structure of society causing poverty; paradoxically, it promotes the adoption of policies that increase people's vulnerability. This discussion concentrates on disaster risk due to natural hazards.

I hereby demonstrate the SFDRR's technocratic understanding of disaster risk obeys to the rationalist epistemological model of risk. However, this model is not designed to trace how human decisions, represented in the social, political and economic structure of society, create poverty, which is a man-made vulnerability to disaster risk, not the result of nature processes. This approach is explained here by locating its origin in the modernisation theory of development.

With this paper I challenge "the dominant or privileged viewpoint" 10 the SFDRR grants to technocracy in understanding disaster risk; thus, the deconstruction method is the preferred one. This method allows dismantling the prevailing SFDRR emphasis on science and technology while bringing to the foreground the constructionist epistemological model of risk, as the one able to trace how human decisions create vulnerability. Although, supporting the constructionist model is politically inconvenient and challenges the modernisation theory of development.

This paper has five sections. In the first one, I review the evolution of non-binding international policy on disaster risk management and reduction, placing emphasis on the shifts regarding their understanding of disaster risk and if they have considered poverty as a vulnerability. In the second section, I discuss why poverty is a driver of disaster risk and the potential effects on policy making of not focusing on poverty but on its consequences. In the third section, I argue why the rationalist epistemological model explains the technocratic SFDRR approach to disaster risk and the non-recognition of poverty as a vulnerability. In the fourth and fifth sections, I analyse the inconveniences of trusting technocracy to solve man-made problems such as vulnerability to disaster risk, and why modernization theory of development constitutes the origin of the rationalist understanding of disaster risk. Finally, I submit my conclusions.

Throughout this paper I will mention the following concepts: indigenous, traditional and local knowledge. There is no universal definition of these terms. ${ }^{11}$ Nevertheless, they overlap and refer generally to "information passed down through generations in a given locality and acquired through the accumulation of experiences, relationships with the surrounding environment,

10 Feldman, S. M. How to be critical. In Chicago-Kent Law Review. 2000. Vol. 76, Issue 2. 910 .

11 Kelman, I., Mercer, J. \& Gaillard, J. C. Indigenous knowledge and disaster risk reduction. In Geography. Vol. 97, Issue 1, 2012, 13. 
and traditional community rituals, practices and institutions." ${ }^{12}$ In this article there is no need to draw the conceptual boundaries between these terms because I will use them to mean the opposite to technocracy; therefore, I will use them as synonymous.

Additionally, in the context of disaster risk reduction frameworks, scientific knowledge encompasses the one that is acquired through technological or technical means. ${ }^{13}$ Then, I will use the term technocracy to embrace this kind of knowledge.

1. THE INTERNATIONAL POLICY EVOLUTION IN

UNDERSTANDING DISASTER RISK: 1987-2030

\section{International Decade for Natural Disaster Reduction}

In December 1987, the UNGA declared the 1990's as a decade to foster international cooperation in the field of natural disasters reduction, and acknowledged that states and their Governments were responsible in designing and implementing policies on this field in cooperation with the UN specialised agencies, the national and international non-governmental organizations and scientific and technological institutions. ${ }^{14}$ The expected outcome of this cooperation was to develop an international framework to support countries to design measures to assess, prevent, predict and mitigate disasters by placing emphasis on a technocratic understanding of their causes and consequences. The UNGA demanded this emphasis because it recognised that scientific and technical knowledge of natural disaster was developed to such extent that it was worth a joint international effort to disseminate and apply it worldwide. ${ }^{15}$

The UNGA designated the 1990's to foster international cooperation motivated by the severe consequences of disasters in the previous two decades: more than 3 million deaths, approximately 800 million people suffered disruption in their livelihood and around $\$ 23$ billion in damages. African countries, landlocked countries, island development countries and in general developing countries suffered most of these consequences, hampering and delaying their development efforts. ${ }^{16}$

12 Ibid.

13 United Nations Office for Disaster Risk Reduction. Report of the UnisdR Scientific and Technical Advisory Group 2013. Available on: https://www.unisdr.org/files/32609_stagreport2013assembled.pdf (accessed 19 July 2019). (Hereinafter UNDRR. Previously known as UNISDR).

14 United Nations General Assembly. International Decade for Natural Disaster Reduction. Res 42/169. 11 December 1987.

15 Ibid., paragraph number 2.

16 Ibid., para 2. 
I want to highlight the 1987 international call to cooperate did not mention anything about poverty as a driver of disaster risk. However, this silent has not been permanent because throughout the international policy evolution in understanding disaster risk, some frameworks on this field have backed it and others not. In the following analysis I refer to these changes, as well as, to the degree these frameworks have emphasised in technocracy to approach disaster risk.

\section{International Framework of Action for the International Decade for Natural Disaster Reduction - IDNDR}

Following the 1987 advice as to placing emphasis on technocracy in understanding disaster risk, the UNGA Secretary General appointed an ad-hoc group of scientific and technical experts on disaster prevention and mitigation to identify existing knowledge and gaps, and to provide recommendations in the implementation of measures regarding this topic. The Secretary General appointed this ad-hoc group to support him in developing the framework for the 1990 's decade. ${ }^{17}$

In December 1989, the UNGA proclaimed the beginning of the International

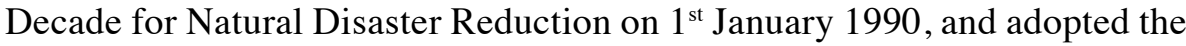
International Framework of Action for the International Decade for Natural Disaster Reduction (IDNDR) aimed at reducing deaths and material damages caused by disasters due to natural hazards. ${ }^{18}$ The IDNDR was adopted based on a report of the ad-hoc group of experts that had been appointed by the UNGA's Secretary General. ${ }^{19}$ As a result of this background, the IDNDR held a technocratic understanding of disaster risk by acknowledging that science and technology were important to assess, predict and mitigate disasters. ${ }^{20}$

Indeed, the recent 2019 Global Assessment Report on Disaster Risk Reduction recognised the IDNDR technocratic approach to this phenomenon, " $[\mathrm{w}] \mathrm{ith}$ a strong emphasis on engaging and deploying existing scientific and technical knowledge, IDNDR succeeded in raising public awareness [...] to move away from fatalism and to reduce disaster losses and impacts." ${ }^{21}$

17 United Nations General Assembly. International Decade for Natural Disaster Reduction. Report of the Secretary General. 20 June 1989. Res A/44/322. 5.

18 United Nations General Assembly. International Framework of Action for the International Decade for Natural Disaster Reduction. 22 December 1989. Res 44/236.

19 United Nations Economic and Social Council. Report of the Secretary-General.Final Report of the Scientific and Technical Committee of the International Decade for Natural Disaster Reduction. Addendum. A/54/132/Add.1-E/1999/80/Add.1. 18 June 1999.

20 See annex para 1 , annex para $2 \mathrm{c}$, annex para $2 \mathrm{~d}$, annex para $3 \mathrm{~b}$ of the IDNDR.

21 United Nations OfFice For Disaster Risk Reduction. Global Assessment Report on Disaster Risk Reduction 2019. Available on: https://gar.unisdr.org/sites/default/files/reports/2019-05/ full_gar_report.pdf (accessed 19 July 2019); emphasis added. 
Regarding the IDNDR and its recognition of poverty as a vulnerability to disaster risk, this framework did not make any reference to this relationship. It remained silent on this topic aligned with the 1987 call to cooperate; neither of them recognised poverty as a driver of disaster risk. However, it is of my surprise that on June 1989 the Secretary General submitted a report to the UNGA containing the executive summary of the ad-hoc group of experts report in which he framed natural disasters as a world problem, and identified poor people as the most vulnerable:

Vulnerability depends on a number of physical, engineering, economic and social factors. Some types of communities and some groups within a given community are particularly vulnerable to natural disasters. For instance, experience shows that the poorest sectors of a population are those with the highest degree of vulnerability. ${ }^{22}$

Nonetheless, the IDNDR neither embraced the Secretary General acknowledgement of poverty as vulnerability to disaster risk nor justified why, but relied on science and technology to understand disaster risk following the UNGA 1987 advice on how to cooperate on this topic and the report of the group of experts. I believe this early approach to disaster risk set up the foundation of the trend that still on place regarding the understanding of this phenomenon. I am going to frame this trend in the following analysis.

\section{Yokohama Strategy and Plan of Action for a Safer World}

Later in 1994, States members of the UN, international organisations, nongovernmental organisations, the scientific community and other stake holders met in Japan to celebrate the World Conference on Natural Disaster Reduction. This Conference took place within the International Decade for Natural Disaster Reduction that had been declared on December 1989 and was driven by the increase of deaths and damages caused by disasters. The Yokohama Strategy and Plan of Action for a Safer World was the outcome of this conference..$^{23}$

Since the 1987 international call to cooperate, the Yokohama Strategy was the first framework in this field to pushback from the initial silence about recognising poverty as a vulnerability to disaster risk. This shift de-emphasised the technocratic understanding of disaster risk held in the IDNDR, allowing

22 United Nations General Assembly. International Decade for Natural Disaster Reduction. Report of the Secretary General (n. 17), 5.

23 World Conference on Natural Disaster Reduction. Yokohama Strategy and Plan of Action for Safer World / Guidelines for Natural Disaster Prevention, Preparedness and Mitigation. Yokohama, Japan. 23-27 May 1994. Endorsed by the un Doc A/CoNF.172/9, 27 September 1994. 
traditional knowledge to be a main means in approaching this phenomenon. ${ }^{24}$ Nonetheless, this pushback did not last for ever and currently the SFDRR does not follow the Yokohama Strategy shift.

The Yokohama Strategy "marked the beginning of a significant shift in the political and analytical context within which disaster reduction was being considered" 25 because it recognised that vulnerability to disaster risk was the result of human decisions ${ }^{26}$ and called to tackle poverty as a means of preventing and mitigating disasters. ${ }^{27} \mathrm{I}$ argue this shift did not displace at all the technocratic understanding of disaster risk held in the IDNDR, but called to apply traditional knowledge as the one able to trace the relationship between human actions and vulnerability. Indeed, the 2019 Global Assessment Report on Disaster Risk Reduction acknowledged the Yokohama Strategy novel approach to this issue:

While IDNDR was largely influenced by scientific and technical approaches, the Yokohama Strategy attributed great importance to socioeconomic vulnerability in disaster risk analysis, emphasizing the crucial role of human actions in reducing the vulnerability of societies to natural hazards and disasters. ${ }^{28}$

Then, I concluded that the Yokohama Strategy allowed traditional knowledge to become the main means in understanding this phenomenon because it could trace how the human activity led to vulnerability, a reasonable shift considering this Strategy recognised vulnerability to disaster risk was the result of human decisions. The Yokohama Strategy assigned technocracy the role of supplementing and reinforcing traditional knowledge. ${ }^{29}$

Hyogo Framework for Action 2005-2015

In 2005 and by appointment of the UNGA, the World Conference on Disaster Reduction in Hyogo, Japan, took place. The aim of this conference was to

24 Ibid., Basis for the Strategy No. 5."Vulnerable developing countries should be enabled to revive, apply and share traditional methods to reduce the impact of natural disasters, supplemented and reinforced by access to modern scientific and technical knowledge" (emphasis added).

25 United Nations Office for Disaster Risk Reduction. Global Assessment Report on Disaster Risk Reduction 2019 (n. 21).

26 World Conference on Natural Disaster Reduction. Yokohama Strategy and Plan of Action (n. 23), principles A1.

27 Ibid., principles 9.

28 United Nations Office for Disaster Risk Reduction. Global Assessment Report on Disaster Risk Reduction 2019 (n. 21), 26 (emphasis added).

29 World CONFERENCE on NATURAL Disaster Reduction. Yokohama Strategy and Plan of Action (n. 23), Basis for the Strategy No. 5; emphasis added. "Vulnerable developing countries should be enabled to revive, apply and share traditional methods to reduce the impact of natural disasters, supplemented and reinforced by access to modern scientific and technical knowledge" (emphasis added). 
update the Yokohama Strategy on the basis of a more systematic effort to disaster risk reduction in the context of sustainable development. The outcome of this Conference was the Hyogo Framework for Action 2005-2015, endorsed by the UNGA. ${ }^{30}$

The Hyogo Framework identified poverty as a vulnerability to disaster risk and acknowledged the link between disaster risk reduction and poverty reduction policies, ${ }^{31}$ pushing back from the 1987 international call to silently cooperate on this relationship. This Framework even made an specific call to end poverty in Africa as a key element in reducing the exposure of African people to hazards and achieve sustainable development. ${ }^{32}$ This recognition happened at the same time the Hyogo Framework held an approach to understand disaster risk underpinned in technocracy and traditional knowledge.

In understanding disaster risk, the Hyogo Framework promoted science and technology for risk assessment and to identify and understand hazards. ${ }^{33}$ Additionally, it called to use technology to achieve an efficient communication of disaster risk information among vulnerable people to allow them build resilience and preparedness for disaster. ${ }^{34}$ The information provided should include traditional and indigenous knowledge as wisdoms that could bring together the technocratic risk assessment and the diversity of recipients on the basis of their cultural and social background. ${ }^{35}$

I have concluded the Hyogo Framework approached disaster risk recognising that tackling this phenomenon required to understand the relationship between the result of human activity, such as cultural and social structures, and vulnerability. Then, it relied on traditional knowledge, the wisdom able to trace this relationship, and technocracy to understand the complexity of hazards, without placing emphasis on any of them.

\section{Sendai Framework for Disaster Risk Reduction 2015-2030}

In 2015, the Third un World Conference on Disaster Risk Reduction in Sendai, Japan took place. It was aimed at updating, the Hyogo Framework and move on to better and more effective strategies for disaster risk reduction. At this conference, countries representatives adopted the ongoing Sendai Framework for Disaster Risk Reduction 2015-2030 which was the result of stakeholder consultations in March 2012 and inter-governmental negotiations

30 World Conference on Disaster Reduction. Hyogo Framework for Action 2005-2015: Building the Resilience of Nations and Communities to Disasters. Kobe, Hyogo, Japan. 18-22 January 2005. Endorsed by the un Doc A/Conf.206/6. 16 March 2005. Preamble B, para 6-7.

31 Ibid., para 4.

32 Ibid., para 27.

33 Ibid., para $17 \mathrm{k}$.

34 Ibid., para $18 \mathrm{~d}$.

35 Ibid., para 18a. 
held between July 2014 and March 2015. ${ }^{36}$ Updating the Hyogo Framework was grounded on the fact that over the previous decade the intensity and frequency of disasters increased causing more than 700 million deaths, over 1.4 injured people, around 23 million people lost their homes and exposure of people and assets to this events increased faster than vulnerability decreased. ${ }^{37}$

The process to adopt the SFDRR had started in 2011 with the UNGA Resolution 66/199 of 22 December. This resolution requested the secretariat of the International Strategy for Disaster Reduction to facilitate the development of the post-2015 disaster risk reduction agenda. ${ }^{38}$ Within this process, in 2013 the Scientific and Technical Advisory Group of the UNISDR ${ }^{39}$ worked on a report about using science for disaster risk reduction and made several recommendations for the new agenda. I want to stress on the recommendation regarding that science and technology were expected to play a key role in understanding disaster risk from 2015 onwards ${ }^{40}$ This confidence on technocracy relied on the believe this kind of knowledge was useful to understand disaster risk, to disaster management and to policy making in this topic. ${ }^{41}$

In the context of building the post-2015 agenda, on December 2013 the un Special Representative of the Secretary-General for Disaster Risk Reduction proposed elements for consideration. Among these proposals, the Special Representative recognised poverty as a vulnerability to disaster risk and called to identify risk as the result of human actions..$^{42}$ On July 2014, the Preparatory Committee of the Third un World Conference on Disaster Risk Reduction suggested elements for the 2015 onward framework, acknowledging poverty as a driver of disaster risk. ${ }^{43}$

Thus, in the process of adopting the SFDRR a UNISDR report intervened, exalting the role of science and technology in the post-2015 agenda, and at the same time the un Special Representative for Disaster Risk Reduction and the Preparatory Committee of the Third un World Conference recognised poverty as a vulnerability to disaster risk. Despite this awareness of the rela-

36 United Nations General Assembly. SFDRR (n. 1), Foreword.

37 Ibid., para 4.

38 United Nations General Assembly. International Strategy for Disaster Reduction. A/ RES/66/199. 22 December 2011.

39 unisdr - The United Nations Office for Disaster Risk Reduction. Nowadays known as UNDRR.

40 United Nations Office for Disaster Risk Reduction. Report of the Unisdr Scientific and Technical Advisory Group 2013 (n. 13), 8.

41 Ibid., Foreword.

42 UNISDR. UN Special Representative of the Secretary-General for Disaster Risk Reduction. Proposed Elements for Consideration in the Pos-2015 Framework for Disaster Risk Reduction. 17 December 2013. para 8, 53. https://www.preventionweb.net/files/35888_srsgelements.pdf (accessed 19 May 2020).

43 United Nations General Assembly. Preparatory Committee of the Third un World Conference on Disaster Risk Reduction. First Session. Suggested Elements for the Pos-2015 Framework for Disaster Risk Reduction. A/CONF.224/PC(I)/6. 14-15 July 2014. 
tionship between disaster risk and poverty, which had been acknowledged by the Secretary General on a report about the ad-hoc group of experts on June 1989, the SFDRR did not incorporate it, but adopted a technocratic approach to disaster risk following the UNISDR report.

Therefore, I believe the SFDRR fall in the early trend in understanding disaster risk by discarding the recognition of poverty as a vulnerability and relying on science and technology, resembling the adoption process of the IDNDR on December 1989. This trend reflects the SFDRR's attachment to the modernisation theory of development; bond that I am going to analyse further in this paper.

Certainly, the SFDRR's paragraph six does not recognise poverty as a vulnerability to be tackled, as the Hyogo Framework and Yokohama Strategy did, but focuses on overcoming its consequences as drivers of disaster risk, "[m]ore dedicated action needs to be focused on tackling underlying disaster risk drivers, such as the consequences of poverty and inequality." ${ }^{44}$ I am going to explore the rationale of this SFDRR shift and its implications in disaster risk reduction policy later in this paper.

Regarding the SFDRR's technocratic approach to disaster risk, its first priority for action calls to rely on science and technology as the main means in doing it, while traditional, indigenous and local knowledge are a complementary source. ${ }^{45}$ In 2019, the un Office for Disaster Risk Reduction recognised the SFDRR approach here explained, "[t]herefore the role of science and technology in providing the evidence and knowledge on risk features heavily in the Sendai Framework." 46

In my opinion, the SFDRR approach to disaster risk is a significant shift, compared with the Yokohama Strategy and the Hyogo Framework, in terms of the role assigned to technocracy and traditional knowledge as means to understanding this phenomenon. While the SFDRR places emphasis on technocracy, the Yokohama Strategy relied on traditional knowledge and the Hyogo Framework embraced both without emphasising on any of them.

44 United Nations General Assembly. SfdrR (n. 1), para 6; emphasis added.

45 Ibid., para 24i; emphasis added. "Priority 1: Understanding disaster risk. To achieve this, it is important: 24(i). To ensure the use of traditional, indigenous and local knowledge and practices, as appropriate, to complement scientific knowledge in disaster risk assessment and the development and implementation of policies, strategies, plans and programmes of specific sectors, with a cross-sectoral approach, which should be tailored to localities and to the context" (emphasis added).

46 United Nations Office for Disaster Risk Reduction. The Science and Technology Roadmap to Support the Implementation of the Sendai Framework for Disaster Risk Reduction 2015-2030. 2016. Available on: https://www.preventionweb.net/files/45270_unisdrscienceandtechnologyroadmap.pdf (accessed 20 July 2019); emphasis added. 
In the previous section I referred to paragraph six of the SFDRR and its focus on overcoming the consequences of poverty, not poverty itself, as a driver of disaster risk. I disagree with this drafting because of the consequences on policy making on this topic.

I consider the efficiency of disaster risk reduction policies is not the same if they are tailored to tackle poverty or its consequences. Being poor -among other things which I do not examine in this paper- is to be vulnerable to disaster risk. This relationship has been pointed by Marie Aronsson-Storrier and Karen Da Costa, "[f]urther individuals sometimes considered especially vulnerable in disasters are those with a disadvantaged socio-economic status." ${ }^{47}$ Similarly, Daniel Fitzpatrick and Caroline Compton argued:

There is substantial comparative evidence that poor, (...) informal landholders are more likely not only to live in hazardous areas, but to be excluded from formal or 'legal' housing markets by the effect of land use planning. ${ }^{48}$

The relationship between poverty and vulnerability to disaster risk is supported by the fact there have been few natural hazards that have affected people, in the same magnitude, regardless of their economic condition. One of these rare examples of disasters, due to natural hazards, took place in 1986 in Cameroon when a carbon dioxide cloud emerged from a lake and poisoned to death 1,700 people, affecting equally poor and rich people.$^{49}$ This rare event, however, did not modify the trend which is that disaster affects more poor people..$^{50}$

This trend is observable by comparing the consequences of the earthquakes which hit Haiti and Chile on 12 January and on 27 February 2010, respectively. Their magnitude was of 7.0 and 8.8 each, but in Chile the earthquake was followed by a tsunami. Despite the earthquake in Chile was stronger than in Haiti, the consequences of this event in the latter country

47 AronsSOn-STORRIER, M. \& DA COSTA, K. Regulating disasters? The role of International Law in disaster prevention and management. In Disaster Prevention and Management. Vol. 26, Issue 5, 2017, 505.

48 FitzPatrick, D. \& Compton, C. Disaster risk reduction and the State: The failure of no-build zones after Typhoon Haiyan. In S AMuel, K. L., AronsSon-Storrier, M. \& Bookmiller, K. N. (eds.), The Cambridge Handbook of Disaster Risk Reduction and International Law. Cambridge: cup, 2019, 299-300; emphasis added.

49 Wisner, B. et al. At Risk: Natural Hazards, People's Vulnerability and Disasters. $2^{\text {nd }}$ ed. London: Routledge, 2003, 9.

50 Samuel, K. L., Aronsson-Storrier, M. \& Bookmiller, K. N. (eds.), The Cambridge Handbook of Disaster Risk Reduction and International Law. Cambridge: cup, 2019, 1. 
were much more devastating. In Chile died 2,4 per 100,000 inhabitants and in Haiti 2,243 per $100,000 .^{51}$

I stress that poverty level in Haiti acted as a driver of the elevated death toll in this country. Haiti's government failure in lifting their population from chronic poverty, by satisfying their human rights, made citizens disproportionately vulnerable to natural hazards. For instance, the chronic unfulfillment of the right to adequate housing in Haiti was linked to the conditions of vulnerability of poor people; most of the 250,000 casualties died crushed by buildings over them in lower middle and poor neighbourhoods. ${ }^{52}$

Conversely, Chile is a prosperous country and its poverty level is much less compared to Haiti, fact which was determinant in the fewer than 600 deaths after the 2010 earthquake and tsunami. ${ }^{53}$ By 2010 , poverty reduction in Chile was achieved by implementing human rights-based approach policies to guarantee access to health services, to adequate housing, to enforce building codes and to satisfy other basic needs, facilitating the authorities' disaster response..$^{54}$

The experiences of Chile and Haiti illustrate how poverty is a vulnerability to disaster risk because this condition restrains people to access decent homes, to health infrastructure, to appropriate land to farm and build, allowing them to reduce their exposure to natural hazards. Poverty pushes people to live in disaster prone conditions such as establishing their homes in flood plains, volcanoes slopes and build weak homes vulnerable to earthquakes and strong winds. Lack of access to wealth and opportunities is the result of how income, assets, knowledge and information are distributed among members of society. ${ }^{55}$

Then, I argue poverty is not the consequence of nature processes, but the result of human decisions represented in how the social, economic and political structures of society distribute economic and non-economic resources and opportunities among its members, defining the extent to which people are vulnerable to disaster risk. Unfortunately, it is politically inconvenient to change these structures because this require modifying how power operates in a society, causing fiercely opposition of groups of interest controlling

51 CARLIN, R. et al.Trust shaken: Earthquake damage, State capacity, and interpersonal trust in comparative perspective. In Comparative Politics. Vol. 46, Issue 4, 2014, 424.

52 Concannon, B. \& Lindstrom, B. Cheaper, better, longer-lasting: A rights-based approach to disaster response in Haiti. In Emory International Law Review. Vol. 25, Issue 3, 2011 , 1165-1167.

53 Ibid.

54 ARBour, M. et al. Lessons from the Chilean earthquake: How a human rights framework facilitates disaster response. In Health and Human Rights Journal. Vol. 13, Issue 1, 2011, 63. Available on: https://cdn1 .sph.harvard.edu/wp-content/uploads/sites/2469/2013/06/ArbourFINAL2.pdf (accessed 23 May 2020).

55 WISNER, B. et al. (n. 49), 5-6. 
resources. ${ }^{56}$ The acknowledgment of poverty as a man-made vulnerability is definitively not new, it might be older than people reading this paper, and constitutes a benchmark for policy making in disaster risk reduction. ${ }^{57}$

Upon establishing the relationship between being poor and vulnerability to disaster risk, I believe the SFDRR's paragraph six is weak and fails to be an efficient guideline in disaster risk reduction policy making. This is because it does not promote the adoption of policies tailored to overcome the origin of poverty by modifying the social, economic and political structures of society. In the next section I illustrate how the SFDRR has, indeed, promoted the adoption of technocratic national policies not tailored to overcome poverty as a vulnerability.

I consider that disaster risk reduction policies will perpetuate vulnerability until they are not designed to tackle the structural causes of poverty. For these reasons, I disagree with SFDRR's paragraph six drafting because it contradicts this framework target which is reducing disaster risk. In other words, the SFDRR has failed to deal with root cause of disaster. ${ }^{58}$

In the next section I explore the epistemological model of risk underpinning SFDRR's denial of poverty as a driver of disaster risk, and its emphasis on technological knowledge to understand and tackle this phenomenon.

\section{EPISTEMOLOGICAL MODELS OF RISK: RATIONALIST AND CONSTRUCTIONIST}

According to David Atkin ${ }^{59}$ and Jan Hovden, ${ }^{60}$ the epistemological debate about risk is circumscribed to whether it can be objectively measured or whether it is subjective and hardly quantifiable. These approaches are the rationalist and the constructionist models, respectively:

Rationalist - The rationalist sees risks as real world phenomena to be measured and estimated by statistics, prioritized by normative decision theory, and controlled by scientific management.

Constructionist - The constructionist sees nothing is a risk in itself. Rather, what we understand to be a risk the constructionist sees as the product of historically, socially, and politically contingent ways of seeing. ${ }^{61}$

56 Ibid., 7.

57 O'KeEFE, P., WestGate, K. \& Wisner, B. Taking the naturalness out of natural disasters. In Nature. Vol. 260, 1976, 566-567.

58 WISNER, B. Five years beyond Sendai. Can we get beyond frameworks? In International Journal of Disaster Risk Science. Vol. 11, Issue 2, 2020, 239, 241.

59 EtKIn,D.Disaster Theory. Amsterdam and Boston: Butterworth and Heinemann, 2016,59.

60 Hovden, J. Risk and Uncertainty Management Strategies. 6th International CRN Expert Workshop: Societal Security and Crisis Management in the 21st Century. Stockholm. 22-24 April 2004. Available on: https://www.files.ethz.ch/isn/13607/Report_CRN_Stockholm.pdf (accessed 5 June 2019).

61 Ibid., 25. 
The rationalist model core argument is that risk exists by itself, so it is an objective phenomenon which occurs naturally independently of subjective considerations tied to human behaviour or expressions such as culture, politics, economics etc. This view is grounded on the scientific method which allows to identify, explain, predict and measure risk through technical means. ${ }^{62}$ In my opinion, this epistemological model is not able to answer the question of how human decisions relate with risk, restraining human capacity to modify or even eliminate a risky situation by changing people's behaviour when this is creating it. I believe the rationalist model allocates in technocracy the whole comprehension of this phenomenon discharging society of its eventual responsibility in managing risk.

Conversely, the constructionist model understands risk by placing emphasis on the topics the rationalist model ignores. It focuses on how human behaviour or expressions such as culture, beliefs, politics and social systems interact between them to produce risk, turning this phenomenon in something which is constantly shaped by the context where it is experienced. ${ }^{63}$ Then, I argue this model allocates on society the responsibility to deal with risk. I stress this epistemological approach empowers people to decide whether live or not at risk; therefore, the definition of what is a risky situation is not the same for everyone but defined by who is experiencing certain context. In summary, under the constructionist model human decisions and activities determine who and what is at risk; phenomenon which is in constant evolution making it difficult, if not impossible, to assess through science and technology.

Therefore, I consider the SFDRR's first priority for action holds a rationalist approach to disaster risk because it places emphasis on technocracy in understanding this phenomenon, not able to trace the causality between human activities and vulnerability. This epistemological choice explains why the SFDRR's paragraph six does not recognise poverty as a driver of disaster risk but the consequences of poverty. In my opinion, tearing apart poverty from its consequences, to focus on the latter one as the objective of disaster risk reduction policies, reflect the political inconveniences of claiming the need to change the social, cultural and economic structures causing poverty. The rationalist model justifies the lack of necessity to modify the root causes of disaster risk because it claims a technocratic approach to this issue, far away from dealing with how people's decisions led to vulnerability.

My concern about the SFDRR's epistemological approach to disaster risk is not limited to a drafting issue, but to its influence on the adoption of national disaster risk reduction policies replicating its epistemological choice. For instance, the Colombian National Disaster Risk Management Plan / a 
development strategy $2015-2025^{64}$ is aligned with the SFDRR's rationalist understanding of risk here explained, it holds a technocratic approach to this phenomenon and does not identify poverty as a vulnerability. According to what I argued in the previous section, the implementation of this national plan has the potential for increasing people's vulnerability to disaster risk because it is not tailored to trace and overcome poverty, a root cause.

I disagree with the SFDRR's epistemological choice because poverty is a driver of disaster risk and is the result of human decisions, relationship that is traced by the constructionist model. Nonetheless, the rationalist model should not be discarded at all. This remains important because allows to understand the complexity of natural hazards that could affect people and how to prevent and mitigate them through technical measures ${ }^{65}$

Then, I propose to understand disaster risk by placing emphasis on the constructionist model because this allows to trace, in the first place, how the social, political and economic structures of society create vulnerability by making people poor. This approach must be complemented by the rationalist model to embrace the complexity of hazards. Although, this is a politically inconvenient endeavour and challenges the modernisation theory of development.

In the next section, I refer to the idea of trusting in technocracy to solve man-made problems such as vulnerability to disaster risk. Framing this idea is important because science and technology are a feature of the modernisation theory of development; theory to which I am going refer in the last section and constitutes the origin of the rationalist understanding of disaster risk.

\section{TECHNOCRACY AND MAN-MADE PROBLEMS}

Alvin M Weinberg asked, "to what extent can social problems be circumvented by reducing them to technological problems?"66 I am sure this question is an invitation to explore the rationale behind the idea of discharging in technocracy the responsibility to solve man-made problems such as vulnerability to disaster risk.

Man-made problems are complex to identify and to solve because they are rooted in people's behaviour and changing human's conduct through social disciplines like law or education is tough. These types of problems

64 Presidencia de la República de Colombia. Decreto n. 308 del 24 de febrero de 2016, "Por medio del cual se adopta el Plan Nacional de Gestión de Riesgo de Desastres". Available on: https://dapre.presidencia.gov.co/normativa/normativa/DECRETO\%20308\%20DEL $\% 2024 \% 20$ DE\%20FEBRERO\%20DE\%202016.pdf and http://portal.gestiondelriesgo.gov.co/Paginas/PlanNacional-Gestion-Riesgo-de-Desastres.aspx (accessed 23 June 2020).

65 WiSNER et al. (n. 49), 5.

66 Weinberg, A. M. Can technology replace social engineering? In Teich, A. H. (ed.), Technology and Man's Future. 3rd ed. New York: St. Martin's Press, 1981, 30. 
are constantly changing and build upon beliefs, gender, age, nationality etc, so a successfully intervention in one place can fail in another place. In my opinion, these difficulties in turning to social disciplines to solve man-made problems justify relying on technocracy to look for a solution because once established an underlying scientific principle this is easy to predict, measure and follow. ${ }^{67}$ I consider the difficulties social disciplines face in changing human behaviour is, indeed, an additional reason that rehearses the political opposition to modify the social, economic and political structures defining the distribution of wealth and opportunities, a driver of disaster risk.

Technocratic intervention in man-made problems just give temporary solutions while people change its conduct as the ultimate solution. ${ }^{68}$ In the context of vulnerability to disaster risk, technocracy alone is unable to change the social, political and economic structures causing poverty because these are built upon human decisions. Definitively, I argue the SFDRR's emphasis on the rationalist understanding of disaster risk is an inefficient guide to design policies to tackle this phenomenon, weakness that has been recognized by M H Glantz by analysing the relationship between technocracy and vulnerability to disaster risk, "[n]o matter how much the science improves, realworld observations of disasters have proven that technologies alone will not effectively reduced disaster's impacts on society." ${ }^{69}$

In summary, I believe the idea of discharging in technocracy the responsibility to solve man-made problems is embedded in the SFDRR because its first priority for action and paragraph six support a technocratic approach to disaster risk, without recognising that vulnerability to this phenomenon is a man-made problem which requires changing human behaviour as the first step to achieve disaster risk reduction.

In the next section I am discussing why technocracy is a feature of the modernization theory of development which constitutes the origin of the rationalist understanding of disaster risk.

\section{DISASTER RISK AND THE MODERNISATION THEORY OF DEVELOPMENT}

Modernisation is the development pathway embedded in the SFDRR and constitutes the origin of this framework technocratic understanding of disaster risk. To explain this idea, I am exploring what is understood by the modernisation theory of development, and technocracy as a feature of this theory.

67 Ibid., 31.

68 Ibid., 31.

69 Glantz, M. H. et al. Working with a Changing Climate, not Against it. Boulder. Consortium for Capacity Building/Instaar, University of Colorado, 2014. 14. Available on: http:// sparetimeuniversity.com/wp-content/uploads/2014/01/ShortExSum_01-16c-14_mhgFINAL2.pdf (accessed 19 July 2019). 
I stress that modernisation cannot be defined with one concept nor a single idea but can be understood through a series of characteristics and processes of society. Then, the best way in which I can describe modernisation is arguing it is a constant process of society developing into a better future, leaving behind a problematic past. ${ }^{70}$ Indeed, modernisation is outlined as a "theory of progressive development." ${ }^{\prime 1}$ This approach to modernisation stands out its feature of unstoppable search for a better future, if a society ceases doing this, it will stop modernising itself and become a traditional or pre-modern society. ${ }^{72}$ Many changes have been identified to fall into the modernisation process; I am going to frame some of them but placing emphasis on science and technology.

Historically speaking, it is not possible to designate a specific date in which the modernisation process started; this is because of its nature of constant change and evolution. However, authors such as A Giddens argued modernisation process began around the $17^{\text {th }}$ century onwards in Europe as certain modes of social, political and economic structures emerged, and became global in their influence ${ }^{73}$ through conquest, colonisation, trade and emulation. ${ }^{74}$

The concepts of nation-state and systematic capitalist production became signposts of the modernisation process because no other political or economic institution established worldwide as they did, to the point they contributed with the construction of globalisation as the current international order. The European origin of these institutions and the "few parallels in prior periods or in other cultural settings" makes the modernisation theory of development a Western project. $^{75}$

Modernisation is also identified with the transition from rural societies, whose livelihood were based in agriculture and traditional practices, to societies dominated by industrial activities and service-based economies. These changes have been drivers of merging modernisation with economic growth, to the

70 Ogborn, M. Modernity and Modernization. In Cloke, P., Crang, P. \& Goodwin, M. (eds.), Introducing Human Geographies. 3rd ed. Hoboken: Taylor and Francis, 2013, 483.

71 Linton, M. D. Modernization. In Paul, J. (ed.), The Sage Encyclopedia of War: Social Science Perspectives. Thousand Oaks: Sage, 2017, 1139.

72 Charlton, B. \& Andras, P. The Modernization Imperative. Exeter: Imprint Academic, 2003,4 .

73 Giddens, A. The Consequences of Modernity, Cambridge: Polity Press, 1990, 1.

74 Charlton, B. \& Andras, P. The Modernization Imperative (n. 72), 15.

75 Giddens. The consequences of Modernity (n. 73), 174-175. Giddens referred to the modernisation process and globalisation in the following terms: "One of the fundamental consequences of modernity, this study has emphasised, is globalisation. This is more than a diffusion of Western institutions across the world, in which other cultures are crushed. Globalisation-which is a process of uneven development that fragments as it coordinates-introduces new forms of world inter-dependence, in which, once again, there are no others." I am not analysing in depth the globalisation process because it exceeds the aim of this paper. 
point the modernisation theory of development has been explained through an economic perspective. Economically speaking, development is achieved through linear stages of economic growth, beginning with the modernisation of society -leaving behind its rural livelihood- and moving on to an urban lifestyle and consuming goods and services massively in the last stage. ${ }^{76}$

From a non-economic perspective, modernisation is known to be the context were democratic regimes are expected to flourish. This expectation is underpinned in people quitting rural and traditional livelihood and establishing new social structures that adopt specialised roles in society, giving birth to a diversity of new political structures.$^{77}$ This variety of political actors do not interact on the basis of theological dogmas and hierarchical relationships, proper of traditional societies, but on a relationship of horizontal interdependence upon their specific functions ${ }^{78}$ This diversity of political actors interact through argumentative debates to build a democratic society. ${ }^{79}$

Others refer to modernisation as a novel life style and social system, where poverty is meant to be eradicated ${ }^{80}$ This understanding of the modernisation process is linked with the economic approach of this theory were the achievement of social benefits depends on economic growth ${ }^{81}$ However, a counter-understanding of this economic approach argue that modernisation perpetuates inequalities, but in a different way than in traditional societies. These new methods are the veiled power relations between political actors who are supposedly building a democratic society through argumentative debates, leaving behind the traditional raw power relations grounded on hierarchy and dogma.$^{82}$

A feature of modernisation is also the reliance of society in scientific and technological principles to understand the surrounding world, instead of the previous theological explanation proper of traditional societies. ${ }^{83}$ This reliance has been so intense that social progress and technocracy have merged into one idea. This entanglement is the basis to consider that science and technology are able to shape social progress because technocracy dominates

76 WiLlis, K. Theories and Practices of Development. 2nd ed. London: Routledge, 2011, 2, 3, 44 .

77 Przeworski, A. \& Limongi, F. Modernization: Theories and Facts. In World Politics. Vol. 49, Issue 2, 1997, 158.

78 Charlton \& ANDras. The Modernization Imperative (n. 72), 3, 5.

79 Dомолокоs, S. Critical theory and political socialization. In Belvedere Meridionale. XXvI, 4, 2014, 58. Available on: http://www.belvedere-meridionale.hu/lapszamok/2014-4/04_ SIK_Belvedere_2014_4_56-63pp.pdf (accessed 21 May 2020).

80 Venn, C. \& Featherstone, M. Modernity. In Theory, Culture \& Society. Vol. 23, Issue 2-3, 2006, 457. Available on: https://www.reading.ac.uk/library/ (accessed 8 May 2019).

81 WiLlis. Theories and Practices of Development (n. 76), 52.

82 Dомопокоs. Critical Theory and Political Socialization (n. 79), 59.

83 SHEPPARD, E. et al. A World of Difference: Encountering and Contesting Development. 2nd ed. New York: Guildford Press, 2009, 54-56. 
human behaviour. ${ }^{84}$ Even M. Heidegger referred to this modern obedience to scientific knowledge by arguing that "man is posed, enjoined and challenged by a power that becomes manifest in the essence of technicity -- a power that man himself does not control." 85

This modern dependence on science and technology has discharged on technocracy the responsibility to understand, prevent and solve problems caused by natural hazards $;{ }^{86}$ therefore, tearing apart the causality between human actions and problems originated in this type of events such as disaster. I believe not recognising this relationship rehearses the modern paradigm of society's emancipation from nature or, ${ }^{87}$ in other words, the denial of the influence of human behaviour on the onset of disasters due to natural hazards, as a way of not establishing public accountability on how society decisions create vulnerability to disaster risk.

Thus, I argue the modernisation theory of development constitutes the origin of the rationalist understanding of disaster risk because this epistemological model is built upon the modernisation feature of unstoppable process of moving on to a better future, leaving behind a traditional society.

On the one hand, I consider the technocratic SFDRR's approach to disaster risk represents the modernisation reliance on science and technology to understand, prevent and solve problems caused by natural hazards such as disaster. On the other hand, this framework not recognition of poverty as a man-made vulnerability embodies the modernisation rupture of the causality between human actions and the onset of disaster triggered by natural hazards. According to the modernisation theory of development, it would not have been possible for the SFDRR to have withdrawn from these approaches because this would have meant interrupting the modernisation process and returning to a pre-modern society. Even though, as I argued throughout this paper, this approach to disaster risk promotes the adoption of policies which increases people's vulnerability.

For these reasons, I believe my proposal of understanding disaster risk through the constructionist epistemological model challenges the modernisation theory of development because science and technology will cease to be a main means in this process. Additionally, it is politically inconvenient.

84 Misa, T. J. The Compelling tangle of modernity and technology. In Misa, T. J., BreY, P. \& Feenberg, A. (eds.), Modernity and Technology. Cambridge, Mass.: mit Press, 2003. 5, 8.

85 Interview to M. Heidegger. Only a God can save us: The Spiegel interview (1966). In SheEhan, T. (ed), Heidegger: The Man and the Thinker. New Jersey: Transaction, 2010, 58.

86 MoL, A.P. The environmental transformation of the modern order. In MISA, T. J., BREY, P. \& Feenberg, A. (eds.), Modernity and Technology. Cambridge, Mass.: mit Press, 2003, 311.

87 LATOUR, B. Love your monsters. In Breakthrough Journal. Issue 2, 2011. Available on: https://thebreakthrough.org/journal/issue-2/love-your-monsters\#body6 (accessed 21 July 2019). 
Throughout this article, I demonstrated the SFDRR approaches disaster risk by placing emphasis on science and technology and non-recognising poverty as a vulnerability. Epistemologically speaking, the SFDRR supports a rationalist understanding of disaster risk.

In deconstructing the SFDRR's epistemologically understanding of disaster risk, I found this approach is grounded on two paradigms: 1) the idea of discharging on science and technology the responsibility to solve man-made problems such as vulnerability to disaster risk, and 2) the modernization theory of development. These two paradigms do not recognize the role of human decisions in creating vulnerability to disaster risk due to natural hazards.

I argued in this paper that poverty is a vulnerability created by human decisions represented in the social, economic and political structures of society which determine how economic and non-economic resources and opportunities are distributed among its members, defining the extent to which people is vulnerable to disaster risk.

Despite the man-made nature of vulnerability, the SFDRR's technocratic understanding of disaster risk is not able to trace how human decisions create the conditions to be poor. This characteristic of the rationalist epistemological model of risk is a weakness of this framework because it promotes the adoption of disaster risk reduction policies not tailored to overcome a root cause of vulnerability. The outcome of this approach is, paradoxically, the promotion of policies that perpetuate vulnerability by their failure to lift people from poverty.

Then, I propose to understand disaster risk by placing emphasis on the constructionist epistemological model because this allows to trace, in the first place, how the social, political and economic structures of society create vulnerability by making people poor. This approach must be complemented by the rationalist model to embrace the complexity of natural hazards. Although, this is a politically inconvenient endeavour and challenges the modernisation theory of development.

\section{REFERENCES}

Arbour, M. et al. Lessons from the Chilean earthquake: How a human rights framework facilitates disaster response. In Health and Human Rights Journal. Vol. 13, Issue 1, 2011. Available on: https://cdn1.sph.harvard.edu/wp-content/uploads/sites/2469/2013/06/ Arbour-FINAL2.pdf (accessed 23 May 2020).

Aronsson-Storrier, M. \& DA Costa, K. Regulating disasters? The role of International Law in disaster prevention and management. In Disaster Prevention and Management. Vol. 26, Issue 5, 2017. 
AronsSon-Storrier, M. Sendai five years on: Reflections on the role of International Law in the creation and reduction of disaster risk. In International Journal of Disaster Risk Science. Vol. 11, Issue 2, 2020.

CARLIN, R. et al. Trust shaken: Earthquake damage, State capacity, and interpersonal trust in comparative perspective. In Comparative Politics. Vol. 46, Issue 4, 2014.

Concannon, B. \& Lindstrom, B. Cheaper, better, longer-lasting: A rights-based approach to disaster response in Haiti. In Emory International Law Review. Vol. 25, Issue 3, 2011.

Charlton, B. \& Andras, P. The Modernization Imperative. Exeter: Imprint Academic, 2003.

Domonkos, S. Critical theory and political socialization. In Belvedere Meridionale. Vol. XXvI, 4, 2014. Available on: http://www.belvedere-meridionale.hu/lapszamok/2014-4/04_ SIK_Belvedere_2014_4_56-63pp.pdf (accessed 21 May 2020).

Etкin, D. Disaster Theory. Amsterdam and Boston: Butterworth and Heinemann, 2016.

Feldman, S. M. How to be critical. In Chicago-Kent Law Review. Vol. 76, Issue 2, 2000.

FitzPatrick, D. \& Compton, C. Disaster risk reduction and the State: The failure of no- build zones after Typhoon Haiyan. In Samuel, K. L., Aronsson-Storrier, M. \& Bookmiller, K. N. (eds.), The Cambridge Handbook of Disaster Risk Reduction and International Law. Cambridge: CuP, 2019.

Giddens, A. The Consequences of Modernity, Cambridge: Polity Press, 1990.

Glantz, M. H. et al. Working with a Changing Climate, not Against it. Boulder: Consortium for Capacity Building/Instaar, University of Colorado, 2014. Available on: http://sparetimeuniversity.com/wp-content/uploads/2014/01/ShortExSum_01-16c-14_mhgFINAL2. pdf (accessed 19 July 2019).

Hovden, J. Risk and Uncertainty Management Strategies. 6th International CRN Expert Workshop: Societal Security and Crisis Management in the 21st Century. Stockholm. 22-24 April 2004. Available on: https://www.files.ethz.ch/isn/13607/Report_CRN_Stockholm.pdf (accessed 5 June 2019).

Interview to M. Heidegger. Only a God can save us: The Spiegel interview (1966). In Sheehan, T. (ed.), Heidegger: The Man and the Thinker. New Jersey: Transaction, 2010.

Kelman, I.; Mercer, J. \& Gaillard, J. C. Indigenous knowledge and disaster risk reduction. In Geography. Vol. 97, Issue 1, 2012.

LATOUR, B. Love your monsters. In Breakthrough Journal. 2, 2011. Available on: https:// thebreakthrough.org/journal/issue-2/love-your-monsters\#body6 (accessed 21 July 2019).

Linton, M. D. Modernization. In Paul, J. (ed.), The Sage Encyclopedia of War: Social Science Perspectives. Thousand Oaks: Sage, 2017.

Lupton, D. Risk. 2nd. ed. Abingdon: Routledge, 2013.

Misa, T. J. The compelling tangle of modernity and technology. In MisA, T. J., Brey, P. \& Feenberg, A. (eds.), Modernity and Technology. Cambridge, Mass.: mit Press, 2003. 
Mol, A. P. The environmental transformation of the modern order. In MisA, T. J., BREY, P. \& Feenberg, A. (eds.), Modernity and Technology. Cambridge, Mass.: Mit Press, 2003.

Ogborn, M. Modernity and modernization. In Cloke, P., Crang, P. \& Goodwin, M. (eds.), Introducing Human Geographies. 3rd. ed. Hoboken; Taylor and Francis, 2013.

O'Keefe, P., Westgate, K. \& Wisner, B. Taking the naturalness out of natural disasters. In Nature. Vol. 260, 1976.

Presidencia de la República de Colombia. Decreto n. 308 del 24 de febrero de 2016, "Por medio del cual se adopta el Plan Nacional de Gestión de Riesgo de Desastres". Available on: https://dapre.presidencia.gov.co/normativa/normativa/DECRETO\%20308\%20DEL\%20 24\%20DE\%20FEBRERO\%20DE\%202016.pdf and http://portal.gestiondelriesgo.gov.co/ Paginas/Plan-Nacional-Gestion-Riesgo-de-Desastres.aspx (accessed 23 June 2020).

Przeworski, A. \& Limongi, F. Modernization: Theories and facts. In World Politics. Vol. 49, Issue 2, 1997.

Sheppard, E. et al. A World of Difference: Encountering and Contesting Development. 2nd ed. New York: Guilford Press, 2009.

UNISDR. UN Special Representative of the Secretary-General for Disaster Risk Reduction. Proposed Elements for Consideration in the Pos-2015 Framework for Disaster Risk Reduction. 17 December 2013.

United Nations General Assembly. International Decade for Natural Disaster Reduction. Res 42/169. 11 December 1987.

United Nations General Assembly. International Decade for Natural Disaster Reduction. Report of the Secretary General. Res A/44/322. 20 June 1989.

United Nations General Assembly. International Framework of Action for the International Decade for Natural Disaster Reduction. Res 44/236. 22 December 1989.

United Nations General Assembly. International Strategy for Disaster Reduction. A/ RES/66/199. 22 December 2011.

United Nations General Assembly. Preparatory Committee of the Third un World Conference on Disaster Risk Reduction. First Session. Suggested Elements for the Pos-2015 Framework for Disaster Risk Reduction. A/Conf.224/PC(I)/6. 14-15 July 2014.

United Nations General Assembly. Sendai Framework for Disaster Risk Reduction 2015 2030. Res 69/283. 23 June 2015.

United Nations General Assembly. Report of the Open-ended Intergovernmental Expert Working Group on Indicators and Terminology Relating to Disaster Risk Reduction. Res 71/644. 1 December 2016.

United Nations Economic and Social Council. Report of the Secretary-General. Final Report of the Scientific and Technical Committee of the International Decade for Natural Disaster Reduction. Addendum. A/54/132/Add.1-E/1999/80/Add.1. 18 June 1999. 
United Nations Office for Disaster Risk Reduction. Report of the Unisdr Scientific and Technical Advisory Group 2013. Available on: https://www.unisdr.org/files/32609_ stagreport2013assembled.pdf (accessed 19 July 2019).

United Nations Office for Disaster Risk Reduction. The Science and Technology Roadmap to Support the Implementation of the Sendai Framework for Disaster Risk Reduction 2015-2030. 2016. Available on: (https://www.preventionweb.net/files/45270_unisdrscienceandtechnologyroadmap.pdf) (accessed 20 July 2019).

United Nations Office for Disaster Risk Reduction. Global Assessment Report on Disaster Risk Reduction 2019. Available on: https://gar.unisdr.org/sites/default/files/ reports/2019-05/full_gar_report.pdf (accessed 19 July 2019).

Venn, C. \& Featherstone, M. Modernity. In Theory, Culture \& Society. 2006. Vol. 23, Issue 2-3, 2006. Available on: https://www.reading.ac.uk/library/ (accessed 8 May 2019).

Weinberg, A. M. Can Technology Replace Social Engineering? In Teich, A. H. (ed.), Technology and Man's Future. 3rd ed. New York: St. Martin's Press, 1981.

WiLLIs, K. Theories and Practices of Development. 2nd ed. London: Routledge, 2011.

Wisner, B. et al. At Risk: Natural Hazards, People's Vulnerability and Disasters. 2nd ed. London: Routledge, 2003.

Wisner, B. Five years beyond Sendai. Can we get beyond frameworks? In International Journal of Disaster Risk Science. Vol. 11, Issue 2, 2020.

World Conference on Natural Disaster Reduction. Yokohama Strategy and Plan of Action for Safer World / Guidelines for Natural Disaster Prevention, Preparedness and Mitigation. Yokohama, Japan. 23-27 May 1994. Endorsed by the UN Doc. A/ CONF.172/9. 27 September 1994.

World Conference on Disaster Reduction. Hyogo Framework for Action 2005-2015: Building the Resilience of Nations and Communities to Disasters. Kobe, Hyogo, Japan. 18-22 January 2005. Endorsed by the un Doc A/Conf.206/6. 16 March 2005. 